\title{
A MÚLT REKONSTRUÁLÁSA A TÖRTÉNETI GENETIKA MÓDSZEREIVEL'
}

\section{RECONSTRUCTION OF THE PAST WITH METHODS OF PALEOGENETICS}

\author{
Kurt W. Alt \\ Danube Private University, Krems, Ausztria; Department of Biomedical Engineering and Integrative Prehistory \\ and Archaeological Science, University of Basel, Svájc \\ kurt.alt@dp-uni.ac.at
}

\section{ÖSSZEFOGLALÁS}

Közel harminc éve a régi DNS-ek vizsgálata az emberiség történetének kutatásában eredményes módszernek bizonyult, és ez mára néhány kezdeti nehézség leküzdése után rutinfeladattá vált. Az emberi fejlődés kérdésein túlmenően fontos eredmények születtek például a Neander-völgyi és a modern ember rokonságával kapcsolatban. Ma az emberi DNS vizsgálata magába foglalja a település- és néptörténet és a vándorlások kutatását, a népcsoportok közötti és belüli rokoni viszonyok rekonstrukcióját, valamint - a régészettel és az orvostudománnyal érintkezésben - őseink egészségi állapotának feltárását.

\section{ABSTRACT}

Ancient DNA analysis has been established as an effective research method for a better understanding of the history of humankind during the past roughly thirty years. Despite the occasional initial difficulties, which ultimately resulted in the definition of authenticity criteria, working with ancient DNA has by now become routine. In addition to questions of human evolution, which, for example, resolved important issues regarding the relationship between Neanderthals and modern humans, the goals of human DNA research today include the study of settlement and population history as well as of human migrations, the reconstruction of kinship relations between and within groups, and the exploration of our ancestors' health condition in collaboration with archaeology and medical research.

Kulcsszavak: régi DNS, néptörténet, településtörténet, rokonság vizsgálata

Keywords: ancient DNA, population history, settlement history, kinship analysis

\footnotetext{
${ }^{1}$ Fordította: Szvicsek Zsuzsanna és Kelemen Andrea.
} 


\section{BEVEZETÉS}

A történeti genetika (,archeogenetika”, „,bioarcheológia”) immár kb. harminc éve alakítja biológiai és történeti tudásunkat az archeo-DNS (aDNS) elemzése révén. A régmúlt aDNS mintáinak feldolgozása során az eredmények értelmezését fơként a DNS hidrolitikus folyamatok általi lebomlása nehezíti. További nehézségeket okoz a DNS fragmentálódása, az egyes nukleotidok és a bázisstruktúra változása. A mintából a DNS kinyerésének abszolút felső határa ötszázezer év körül mozog. A mintát feldolgozó személyek által bevitt szennyeződés, valamint a hitelesség kritériumaihoz való ragaszkodás további fontos szempontok az aDNS feldolgozása során (Hofreiter et al., 2001; Willerslev-Cooper, 2005). Az emberi DNS kutatása területén a csoportokon belüli, illetve csoportok közti családi kapcsolatok rekonstruálása, valamint őseink egészségének és betegségeinek vizsgálata áll az emberi populációs, evolúciós és a migrációs folyamatokkal foglalkozó tudományág középpontjában. A kezdeti nehézségek után a történeti genetika megalapozása az 1990-es években történt meg (Pääbo, 1985; Stoneking, 1995; Richards et al., 1993; Herrmann-Hummel, 1994), az aDNS vizsgálatának kezdetei óta az emberi maradványokon túl a növényi, állati mintákon, valamint üledékeken és szerves maradványokon végzett kutatások is az eszköztárához tartoznak (Herrmann, 1994). Ezzel egy időben a humán- és populációgenetika egyre intenzívebben kezdett foglalkozni az emberiség eredetével és fejlődésével (Brenner-Hanihara, 1995; Cavalli-Sforza, 1996), ez ma számos publikáció tárgyát képezi (Pääbo et al., 2004; Hagelberg et al., 2015; Haber et al., 2016; Hofreiter et al., 2014; Willerslev-Cooper, 2005; Orlando et al., 2015; Slatkin-Racimo, 2016). A továbbiakban Európa benépesülésére és népességtörténetére összpontosítunk.

\section{A HOMO SAPIENS EVOLÚCIÓJA?}

Az anatómiailag modern ember (Homo sapiens) bölcsője, ahonnan minden ma élő ember származik, egyértelmüen Afrikában volt (Stringer, 2016). Ezen a földrészen alakult ki a $H$. sapiens kb. 250000 évvel ezelőtt különféle ősi afrikai populációkból (Hammer et al., 2011). A H. rhodesiensis/H. heidelbergensis leszármazottai genetikailag fejlettek voltak, egymással szoros kapcsolatban álltak, genetikai anyagukat évezredeken át cserélték ki egymás között, és az egész afrikai kontinensen elterjedtek (Wood-Lonergan, 2008). Mintegy 125 000-60 000 évvel ezelőtt áramlott ki a H. sapiens Afrikából Európába és Ázsiába, ahol kb. 45000 éve vált tömegessé a jelenléte (Hammer et al., 2011), itt találkozott az eurázsiai őslakosokkal: a Neander-völgyi emberrel és a gyeniszovai emberrel (Finlayson, 2004). A csoportok közti együttélés - a kompatibilitási határok ellenére - közös leszármazottakhoz is vezetett, melynek nyomait a saját örökítőanyagunkban ma 
is láthatjuk (Fu et al., 2014; Kuhlwilm et al., 2016; Mallick et al., 2016); a mai európaiak/délkelet-ázsiaiak DNS-ének néhány százaléka a Neander-völgyi (Vernot-Akey, 2014; Sankararaman et al., 2014; Racimo et al., 2015), illetve a gyenyiszovai emberre vezethető vissza (Reich et al., 2010; Sankararaman et al., 2016). A 45000 évvel ezelőtt Európában letelepedő, anatómiailag modern ember nem volt a mai európaiak közvetlen őse (Fu et al., 2016), csupán azok, akikből a kb. 37000 évnél fiatalabb emberi maradványok származnak, tekinthetők egyértelmüen őseinkként. Habár a drámai éghajlati események az utolsó nagy jégkorszak során az eredeti észak- és közép-európai populációt visszahúzódásra kényszerítették Délnyugat-Európa irányába, genetikai folytonosság mutatható ki a jégkorszak előtti és az eljegesedés csúcspontja után Közép-Európába visszatelepült emberek között. Újabb bizonyítékok alapján az európai és a Közel-Keleten élő emberek közötti szoros rokonság a jégkorszaki, azonos területen való együttélés következményének tekinthető. A mtDNS (mitokondrium) adatok további kiértékelése világított rá arra, hogy milyen mélyreható demográfiai változások zajlottak le ezekben az időkben (Posth et al., 2016): ezek egyetlen, átfogó és gyors elterjedési hullámot sugallnak. (Érdekes módon a mtDNS Hg M - egy, a mitokondrium oxidatív funkcióit érintő mutáció, amely a mai európaiakból hiányzik, az ázsiai és az őshonos amerikai és ausztráliai lakosságban széles körben elterjedt, még megtalálható az utolsó jégkorszak kiteljesedése előtti időből származó közép-európai mintákban. Feltételezhetjük, hogy az emberi populációk visszahúzódása a mérsékeltebb klímájú Dél- és Délnyugat-Európába a jégkorszak leghidegebb időszakában zajlott le, ahonnan később a felmelegedés során visszatértek Közép- és Észak-Európába, ami hozzájárult a Hg M elvesztéséhez.)

\section{POPULÁCIÓTÖRTÉNET ÉS NÉPESSÉGFEJLŐDÉS AZ ÚJKŐKORSZAKBAN}

Az aDNS-kutatások középpontjában az elmúlt tizenöt évben a neolitikumban lezajlott európai letelepedés történetének időrendiségét vizsgáló populációgenetikai tanulmányok álltak. Ezek elsősorban azt voltak hivatottak eldönteni, hogy a mezőgazdaság és az állattenyésztés európai elterjedése a Közel-Keletről érkezett bevándorlók területfoglalásának vagy csak a megfelelő tudás átkerülésének volt-e köszönhető. Előzetes kutatások (Haak et al., 2005; Bramanti et al., 2009) után nagy mintaszám bevonásával végeztek vizsgálatokat Európa három központi jelentőségü régiójában: Közép-Németországban, a Kárpát-medencében és az Ibériai-félszigeten. Az eredmények, melyek fóként mtDNS-kutatásra alapultak, rendkívüli módon kiszélesítették látókörünket az újkőkorszak kezdetéről és lefolyásáról a korai bronzkorig, valamint felbecsülhetetlen értékü ismereteket nyújtottak az adott kor szereplöiről. A legfontosabb eredményeket összefoglalva: megerösítést nyert az a feltételezés, hogy a Kárpát-medence folyosóként mü- 
ködött Közép-Európa neolitizációs folyamatai során. Összehasonlítva a dél-dunántúli Starčevo-kultúrát (Kr. e. 6200-5450 között létezett kultúra - a fordító megjegyzése) és az azt követő vonaldíszes kerámia kultúrát a Közép-Európában vonaldíszes kerámiát használó populációval, a genetikai profiljukban nagy hasonlóságot lehet kimutatni, ami közös eredetre utal (Szécsényi-Nagy et al., 2014; 2015). Mind a mtDNS, mind pedig az Y-kromoszomális adatok azt támaszják alá, hogy a Starčevo-populáció a Közel-Keletről és Délnyugat-Ázsiából származik (Szécsényi-Nagy, 2015; Keerl, 2014). A neolitikus földművesek megérkezésére Közép- és Nyugat-Európa már ott élő vadászó-gyüjtögető népessége különböző módon reagált. Közép-Európában, a Közép-Elba-Saale területen a bevándorlók kezdetben lecserélték a helyben élő vadászó-gyüjtögető csoportok nagy részét, melynek során párhuzamos társadalmak jöttek létre. Meglepő módon - a korábbi vadászó-gyüjtögető népek északi leszármazottainak visszatérése révén - a tölcséres szájú edények kultúrája (Kr. e. 4200-2800 között Közép-Európa északi, Kelet-Európa középső részén és Dél-Skandináviában kialakult paraszti kultúra a fordító megjegyzése) elterjedése idején egy közös génállomány jött létre.

Az újkőkorszak végén elsősorban a zsinegdíszes kerámia kultúrával jellemezhető populációnak a sztyeppékről való vándorlása járult hozzá a jelenlegi európaiak további genetikai sokszínűségéhez. Ezzel szemben az Ibériai-félszigeten az újkőkorszaki letelepedés egészen máshogy zajlott le. Már a korai földmüvesek megérkezésének idején erős volt a keveredés a helyi lakosok és a bevándorlók között. A genetikai diverzitás ott a legnagyobb, ahol az újkőkori, a Közel-Keletről származó bevándorlók az őslakosokkal a legközelebbi kapcsolatba kerültek: az Ibériai-félsziget északkeleti részén és az Ebro-völgyben (Szécsényi-Nagy et al., 2017). Szembetűnő, hogy a korai bronzkorba való átmenet idején az új lakosság keleti sztyeppékről történt beáramlása Közép-Európában genetikailag erősen megmutatkozik (Haak et al., 2015), ez a spanyolországi és portugáliai korai bronzkor mtDNS-adataiban azonban még nem bizonyítható. Az eredmények azt mutatják, hogy a jelenlegi genetikai variabilitás kialakulása egy komplex folyamat következménye, és nem magyarázható a helyi vadászó-gyüjtögető lakosok és a Közel-Keletről bevándorló földművesek egyszerü keveredésével.

A genom kutatásának (az emberi DNS összessége - a fordító megjegyzése) megjelenése a letelepedés történetével kapcsolatos korábbi állítások pontosságát jelentősen megnövelte. A teljesgenom-vizsgálatokhoz előzetes kutatások alapján olyan mintákat választottak ki, melyek nagy mennyiségü eredeti DNS-t tartalmaztak. Az első, egész genomon alapuló tanulmány kilenc őskori ember és 2345 modern kori személy publikált genomikai adatainak összehasonlítása volt (Lazaridis et al., 2014). Az eredmények alapján három, élesen elkülönülő ősi csoport körvonalazódik, melyekhez a ma élő legtöbb európai ember társítható: a nyugat-európai vadászó-gyüjtögetők, akik minden európai leszármazásához hozzájárultak, az észak-eurázsiaiak, akiknek a nyomai megtalálhatók a közép- és kelet-európai csoportokban, és a 
korai földmüvesek, akik anatóliai és levantei bevándorlóként érkeztek Európába, de mind Nyugat-, mind pedig Kelet-Európában letelepedtek. Az hogy egyre nagyobb mintákon lehetett genomszintü vizsgálatokat végezni, az európai lakosság eredetének és összetételének, valamint a kontinens ,gyarmatosításának” alaposabb megismerését eredményezte (Mathieson et al., 2015; Haak et al., 2015; Rasmussen et al., 2014). A bevándorló földmüvesek genetikailag jelentősen különböztek az őslakos vadászoktól és gyüjtögetőktől az összes vizsgált földrajzi régióban. Az orosz sztyeppék kortárs Jamnaja-kultúrája állattenyésztői (a Jamnaja az orosz sztyeppéken élő népek egyik kultúrája - a fordító megjegyzése) szintén eltérő genetikai profilt mutatnak, mely a kelet-európai vadászó-gyüjtögetőktől és a dél-kaukázusi népcsoportoktól való leszármazást mutatja, a korai levantei földmüvesek befolyása azonban nem mutatható ki náluk. A Jamnajával szoros rokonságban álló zsinegdíszes kerámia kultúra által terjedt el a „sztyeppe genetikai jel” keletről nyugat felé, ami akkortól kezdve megtalálható volt szinte minden bronzkori kultúrában, és jelen van a mai európaiakban is. Ez a Kr. e. 3. évezredben lezajlott esemény tekinthető a második nagy, Európába irányuló bevándorlási hullámnak a korai földmüvesek Kr. e. 6. évezredben a Közel-Keletről történt migrációja után.

A genomvizsgálatok a Termékeny félhold (a Közel-Kelet egy félhold alakú területe, amely Mezopotámiát, a Kánaánt és a Nílus-völgyet foglalta magában) első földmüvesei genetikai szerkezetével kapcsolatos ismereteinket is gazdagították. Ezek szerint a Közel-Kelet lakosságának körülbelül a fele „őseurázsiai” ősökhöz köthető; náluk a Neander-völgyi génekkel való keveredés alig mutatható ki (Lazaridis et al., 2016), már korábban el kellett különülniük más, nem afrikai származási vonalaktól, mielőtt további csoportok létrejöttek volna belölük. Dél-Levante és a Zagros-hegység legelső földmüvesei genetikailag nagyon eltérők voltak, és valamennyi a helyi vadászó-gyüjtögető csoportoktól származott. A bronzkorban lezajlott csoportok közötti, valamint az anatóliai földmüvesektől származó további génáramlás során azonban genetikailag olyan keveredés jött létre, hogy a köztük lévő genetikai különbségeket már nem lehet kimutatni. A közel-keleti földmüvesek és a környezö területek lakosai közti csoportdinamika változatos hatású volt: az anatóliai földmüvesek nyugatra (Európa), a levantei parasztok dél felé (Kelet-Afrika), az iráni földmúvelők északra vándoroltak (eurázsiai sztyeppék). Azok a csoportok, amelyek kapcsolatban álltak mind a korai iráni földmüvesekkel, mind az eurázsiai sztyeppék pásztoraival, kelet felé terjeszkedtek (Dél-Ázsia). Az eredményeket további, ezeken a területeken elvégzett genomvizsgálatok is alátámasztják (Broushaki et al., 2016; Hofmanová et al., 2016; Gallego Llorente et al., 2016). Hosszan tartó változások jöttek létre a Termékeny félhold újkőkori közösségeiben a gyüjtögető felhasználóiból a termelői gazdálkodásra való átállás során. A régészet számára különösen tanulságos, hogy míg a Termékeny félhold összes neolitikus csoportja kulturálisan nagyon közel állt egymáshoz, genetikailag igen különbözőek voltak. 


\section{EURÓPA ÁTALAKUL - A NÉPESSÉG FEJLŐDÉSE A BRONZKORBAN}

A bronzkor (Kr. e. 3. évezred) a kulturális változások időszaka volt, ami az élet minden területét érintette: a gazdasági és társadalmi körülményeket, a temetkezési szokásokat. (Hansen-Müller, 2011; Kristiansen, 2012). Közép-Európában a zsinegdíszes kerámia müvelői voltak ennek a fejlődésnek az úttöröi, amit megerösít egy, európai és közép-ázsiai mintákon elvégzett genomszintủ vizsgálat (Allentoft et al., 2015). Számos közép-európai, a zsinegdíszes kerámia kultúrához tartozó személy feltünően közeli genetikai hasonlóságot mutat a Jamnaja-kultúra tagjaival. A hasonlóság oka valószínűleg a lovas nomádok tömeges bevándorlása volt, illetve keveredésük a helyi földmüvesekkel. Minthogy a Jamnaja-kultúrához tartozók messze eljutottak, és nagy mobilitás jellemezte őket, így feltételezhető, hogy az indoeurópai nyelvek egyes ágai ezen sztyeppei népek által kerültek Európába (Haak et al., 2015). A bronzkori ázsiai bevándorlók vizsgálata továbbá alátámasztja azt az elképzelést, hogy ők hozták magukkal a laktóz lebontásának képességét, ugyanis ez a mutáció először a késő bronzkorban jelenik meg Közép-Európában (Allentoft et al., 2015; Mathieson et al., 2015). (Eddig azt feltételezték, hogy először a Közel-Keleten, a Balkánon vagy a Kárpát-medencében élő földműveseknél alakult ki a tej felnőttkori lebontásának képessége, majd az újkőkori átmenet keretén belül terjedt el egész Európában [vö. Burger et al., 2007].)

\section{EURÓPA LAKOSSÁGA A VASKORBAN, A RÓMAI BIRODALOM IDEJÉN ÉS A KÖZÉPKORBAN}

Genomszintű vizsgálatok azt mutatják, hogy az európaiak őstörténete különböző eredetű csoportok keveredésével zajlott le, ami a népvándorlásoknak köszönhető. Ezen csoportok között megtalálhatók a bennszülött középső kőkorszaki vadászó-gyüjtögetők, a Közel-Keletről bevándorolt telepesek és az eurázsiai sztyeppékről származó nomádok, akik elözönlötték a bronzkori Európát. Amennyire lenyügöző az európai őstörténetben a népességfejlődés dinamikája, ezt a genetikai sokféleségben, differenciációban visszalépés követte, és a bronzkorban elért arra a szintre, amelyet a mai Európában is megfigyelhetünk (Lazaridis et al., 2016). A genetikai differenciálódás drámai csökkenése kihívás elé állítja a populációgenetikusokat. Minthogy a késői bronzkortól kezdve a populációk genetikai profilja igen hasonló egymáshoz, ez nagyon megnehezíti a korai bronzkornál fiatalabb népcsoportok keveredési és vándorlási eseményeinek feltérképezését. A módszertani lehetőségek hiánya miatt eddig sikertelenek voltak azok a molekuláris genetikai próbálkozások, melyek Európa újabbkori történelmének struktúráját és dinamikáját voltak hivatottak feltárni. Egy újonnan kifejlesztett módszer segítségével, mely genomadatok alapján a ritkán előforduló genetikai variációk egyezése segítségével képes megállapítani egyének és csoportok közös genetikai leszármazását, 
lehetségessé vált a történelmi idők népcsoportjainak vizsgálata genetikai eredetük és összetételük megállapítására. Az egyik első ilyen tanulmány a Kr. u. 400 körül Nagy-Britanniába történt angolszász bevándorlás és a mai brit társadalom genetikai állományának kapcsolatára fókuszált: a késő vaskorban és a korai középkorban Cambridge-ben élt személyek genomszekvenciáit vizsgálták (Schiffels et al., 2016 [és lásd Jörg Feuchter és Koncz István cikkét e szám 126-132. és 133-139. oldalain]). A vaskori népességváltozások részletesebb megismerése azért fontos, hogy jobban megértsük az európai történelem populációgenetikai alakulását. A vaskor jelenti ugyanis az utolsó, nagy átfogó kort a római kori átalakulások előtt. Ezért szükség lenne egy olyan nemzetközi projektre, amely részletesen tanulmányozza az emberi népesség vaskori történelmét. Sajnos jelenleg alig van vaskori genomi adat (Martiniano et al., 2016; Schiffels et al., 2016).

A Római Birodalom kialakulása, a népvándorlás zürzavara, majd Európa számtalan régióra való tagolódása olyan dinamikus népesedési folyamatokkal járt együtt, ahol a szereplőket nem könnyü besorolni. Átfogó tanulmányok készültek az elmúlt években a Kr. u. 5-6. században lezajlott európai népvándorlással kapcsolatban. Vajon miért változtatták meg a népcsoportok a lakhelyüket ilyen nagy távolságokon át? Csak kis csoportok vándoroltak Európán keresztül, vagy a migráció tömegesen zajlott? Ezek megválaszolását sokáig akadályozta az írott források korlátozott jellege vagy megbízhatatlansága, valamint a régészek és a történészek között zajló viták. A történeti genetika és az izotópos vizsgálati módszerek együttes alkalmazásával az elmúlt években elsősorban a langobárdokkal kapcsolatban foglalkoztak (ezeket még a genomikai vizsgálatok korszaka előtt végezték el). A Somogy megyei Szóládon feltárt 6. századi temető integrált mintaelemzésre adott lehetőséget (Alt et al., 2014). Meglepő az itt talált közösség csonttani és genetikai heterogenitása, sokfélesége, ami kevés bizonyítékkal szolgál arra nézve, hogy a személyek között közvetlen anyai rokonság lett volna. Emellett nagyfokú mobilitást is sikerült kimutatni: a stronciumizotópos vizsgálatok szerint csak a gyerekek születtek helyben, valamennyi huszonöt-harminc évnél idősebb felnőtt másutt. Ez egybecseng a történeti forrásokkal és a feltárást végző régészek megfigyelésével: ez a település csak körülbelül egy nemzedéken át állt fenn. Az izotópos jelek patrilokális, a letelepedésnél a férfiágat előnyben részesítő letelepedési szabályokat valószínüsítenek, és azt jelzik, hogy az eredeti, utolsó lakóhelyük nem volt túl messze Szóládtól, ugyanakkor kevés jel utal arra, hogy távolról érkeztek volna - mindeközben a régészeti leletek dél-, nyugat- és közép-németországi, morvaországi, közép-dunai és itáliai csoportokkal való kulturális kapcsolatokra utalnak! Nyilvánvaló, hogy nem egy zárt szaporodási közösséget alkotó, hanem mobil személyekböl álló, nyílt csoportról van itt szó. Vizsgálataink tehát alátámasztják a történeti kutatás azon nézetét, mely szerint a langobárdok nagyon mobilis életformát folytattak, és csak rövid ideig éltek Pannóniában. 
Nehezebb dolgunk van, ha a népvándorlásokat az európai történelem részeként kívánjuk szemlélni. Milyen társadalmi felépítése és szervezettsége (például társadalmi pozíció, rokonság) volt a katonai és mozgékony életmódot folytató közösségeknek, kiket temettek el a temetőikben? Vajon a helyváltoztató életmód föszereplöit-e: a helyieket vagy pedig mind a bevándorlókat, mind a bennszülött lakosságot? A langobárdokat nézve: milyen bizonyítékok vannak az itáliai honfoglalásukra, és hogy Pannóniából származtak? Valóban idegenek-e a temetőkben talált személyek, és ha igen, milyen mértékben? Hogy a kora középkorban jelentősen megnövekedett az emberek mobilitása Európában, az nemcsak régészeti és történeti forrásokból, de a migrációkkal kapcsolatos, jelenleg folyó természettudományos vizsgálatokból is tudott (Pohl, 2008; Vida, 2008; Tütken et al., 2008; Knipper et al., in press). Az észak-itáliai Piemont tartományban feltárt sírok történeti genetikai elemzései olyan mtDNS-haplotípusokat (az egy adott DNS-molekulán található genetikai variánsok - a fordító megjegyzése) azonosítottak, melyek kivétel nélkül nyugat-eurázsiai makrohaplocsoportokat tükröznek, és bizonyítják a leszármazásbeli folytonosságot a középkortól napjainkig (Vai et al., 2015). Ezen túlmutató eredmények azonban már csak genomszintű adatoktól várhatók.

A kora középkori népcsoportok genetikai összetételéről eddig csupán néhány elemzés készült. Egy, a magyarok és szlávok 9-12. század közötti érintkezési zónájáról készült tanulmány a mtDNS-haplotípusok erősen heterogén összetételét mutatta ki egy alapvetően európai jellegủ génállományon belül, és nagy hasonlóságot állapított meg a modern európaiakkal (Csákyová et al., 2016). Még árnyaltabb az a tanulmány, amely az avar korból (7-9. század), a honfoglalás időszakából (9-10. század) és a magyarok honfoglalása utáni időszakából (10-12. század) származó mtDNS-minták alapján készült (Csősz et al., 2016). Míg az avar csoportok génállománya kelet- és dél-európai, addig a „hódítóké” nyugat-, középés észak-eurázsiai népcsoportok keverékének jellegeit látszanak mutatni, náluk a finnugor gyökerek ugyanúgy tetten érhetők voltak, mint a „török” és közép-ázsiai hatások. Az eredmények összhangban vannak azokkal a történeti folyamatokkal, melyek a középkori magyar népesség kialakulásához vezettek. A mtDNS-kutatások azonban ezen a ponton elérték a korlátaikat, genomszintủ adatok használatával és nagyobb felbontóképesség elérésével lehetővé válhat a múlt még részletesebb feltárása; az első ilyen jellegủ vizsgálatok már meg is kezdődtek.

\section{ÖSSZEFOGLALÁS}

Alapvetően a késő újkőkorszakban alakult ki az európaiak jelenlegi génkészlete, amely azóta kicsit módosult ugyan, de lényegében változatlan maradt (Brandt et al., 2013; Haak et al., 2015; Mathieson et al., 2015). Az európai génállomány a korai bronzkortól kezdve kis változatosságot mutat, és nehezen elemezhető a 
hagyományos módszerekkel. Sem a mtDNS és az Y-kromoszóma adatai, sem pedig az autoszomális (testi kromoszómák - a fordító megjegyzése) genomadatok nem képesek a vándorlások és a népcsoportok letelepedési történetének finomabb felbontására. Stephan Schiffels és munkatársai (2016) vizsgálata egy lehetséges kiutat mutat ebből a helyzetből egy olyan, ritka génvariánsokon alapuló elemzés segítségével, mely a genetikai profilok jobb minőségü felbontásához vezethet. Bár az ilyen tanulmányokhoz szükséges módszertani lehetőségek elvileg már megvannak, de biztosan szükség lesz még néhány évre, míg - a terveknek megfelelően - nagyobb mintaszámon is tesztelik azokat. Amikor a genomszintü vizsgálatok kora előtti időből származó eredmények megbízhatóságát értékeljük, akkor figyelembe kell vennünk a használt modellek jellegzetességeit, valamint alkalmanként a kis mennyiségü rendelkezésre álló adatot is. Hasonlóképpen, az ismétlődő (kisebb) genetikai keveredések és a (diszkrét) elkülönüléshez vezető események meghatározása is gondot okoz. Sokkal könnyebben vonható le következtetés olyan esetekben, amikor a helyi genetikai profilban egy távoli, kiugró értéket találnak (Xie et al., 2007). A genetikai markereknek a kontinensek közötti, már régen kialakult eltérő eloszlása alapján például az afrikai és ázsiai bennszülöttek vagy az amerikai és ausztrál őslakosok genetikai vonalai nehézség nélkül megkülönböztethetők az európaiakétól, és ez fordítva is igaz.

A populációkkal kapcsolatos adatok értelmezésében fontos az a tény, hogy a régészeti kultúrák sem nem tényleges, sem nem teoretikus tükröződései a „népeknek", amint a biológiai egységek sem, ahogyan ez nagyon sok mai ember történelemszemléletében jelen van. A társadalmi csoportok vagy társadalmi identitás meghatározása anyagi, kulturális vagy egyéb hasonlóságok mint etnikai csoportosítás alapján minden kultúrtörténettel foglalkozó tudományágat áthat (Jones, 1997; Derks-Roymans, 2009). Csak a közelmúltban lett azonban ez a megközelítés - legalább részben - politika- és ideológiamentes, habár a régészeti kultúrákat továbbra is gyakran etnikai egységek leképeződésének tekintik (Fernandez-Götz, 2008; Brather, 2004; Burmeister-Müller-Scheeßel, 2006). Sebastian Brather és Hans-Peter Wotzka (2006) szerint a „régészeti etnikumok” rekonstrukciója párhuzamosan alkalmazandó a hagyományos „régészeti kultúra” fogalmával, annak érdekében, hogy jobban megértsük a népvándorlás korát és a korai középkort. Az etnikai identitás sem biológiailag, sem pedig társadalmilag nem tekinthető merev kategóriának, a változékony régészetikultúra-meghatározások miatt a tárgyi emlékeken alapuló „kultúrák” pedig nem jellemeznek diszkrét populációkat. Az őskori és a korai történelmi idők kultúrái esetében az etnikumokban való gondolkodás nem vezet eredményre, és a kulturális hozzárendeléseknek mindig mesterséges színezetük van. Ezért a populációgenetikai adatokat mindig relatív és abszolút időrendben kell értelmezni. A genetika már megszabadult attól, hogy embercsoportokhoz etnikai/kulturális jegyeket kapcsoljon. Az adott másodlagos, átvitt jelentéstől függetlenül a genetikai markerek változásának detektálása lehetséges teljes 
genomokban és időbeli dimenzióban. Ugyanígy lehetséges a letelepedés- és populációtörténelem vizsgálata során a családfákban megjelenő változások láthatóvá tétele a maguk sokszínűségében, kiterjedtségében és összefüggéseiben. Kívánatos lenne, ha a társadalom- és természettudományok közötti párbeszéd folyamán lehetne elvégezni az adatok végső osztályozását és értelmezését.

\section{IRODALOM}

Allentoft, M. E. et al. (2015): Population Genomics of Bronze Age Eurasia. Nature, 522, 167-172. DOI: 10.1038 /nature 14507

Alt, K. W. (2014): Lombards on the Move - An Integrative Study of the Migration Period Cemetery at Szólád, Hungary. PLOS ONE, 9(11): e110793. DOI: 10.1371/journal.pone.0110793, http:// journals.plos.org/plosone/article?id=10.1371/journal.pone.0110793

Bollongino, R. et al. (2013): 2000 Years of Parallel Societies in Stone Age Central Europe. Science, 342, 479-481. DOI: 10.1126/science.1245049, http:/www.synthesys.info/wp-content/ uploads/2013/08/Science-2013-Bollongino-science.1245049.pdf

Bramanti, B. et al. (2009): Genetic Discontinuity between Local Hunter-Gatherers and Central Europe's First Farmers. Science, 326, 5949, 137-140. DOI:10.1126/science.1176869, http://www. roceeh.net/fileadmin/download/Publications/Bramanti_Sci09_Meso_Neo.pdf

Brandt, G. et al. (2013): Ancient DNA Reveals Key Stages in the Formation of Central European Mitochondrial Genetic Diversity. Science, 342, 6155, 257-261. DOI: 10.1126/science.1241844 /http://www.ufg.uni-kiel.de/ufg-nopl144/dateien_studium/Archiv/2015_HS Furholt/Literatur/ Science-2013-Brandt-257-61.pdf

Brather, S. (2004): Ethnische Interpretationen in der frühgeschichtlichen Archäologie. BerlinNew York: Walter de Gruyter

Brather, S. - Wotzka, H. P. (2006): Alemannen und Franken? Bestattungsmodi, ethnische Identitäten und wirtschaftliche Verhältnisse zur Merowingerzeit. In: Burmeister, S. - Müller-Scheeßel, N. (Hrsg.): Soziale Gruppen, kulturelle Grenzen. Die Interpretation sozialer Identitäten in der Prähistorischen Archäologie. (Tübinger Archäologische Taschenbücher 5) Münster-New York-München-Berlin: Waxmann, 139-224.

Brenner, S. - Hanihara, K. (eds.) (1995): The Origin and Past of Modern Humans as Viewed from $D N A$. Singapore: World Scientific. DOI: 10.1142/9789814293181

Broushaki, F. et al. (2016): Early Neolithic Genomes from the Eastern Fertile Crescent. Science, 353, 499-503. DOI: 10.1126/science.aaf7943, http://science.sciencemag.org/content/ early/2016/07/13/science.aaf7943.full

Burger, J. et al. (2007): Absence of the Lactase-persistence-associated Allele in Early Neolithic Europeans. Proceedings of the National Academy of Sciences of the USA, 104, 10, 3736-3741. DOI: 10.1073/pnas.0607187104, http://www.pnas.org/content/104/10/3736.full

Burmeister, S. - Müller-Scheeßel, N. (Hrsg.) (2006): Soziale Gruppen - kulturelle Grenzen. Die Interpretation sozialer Identitäten in der Prähistorischen Archäologie. (Tübinger Archäologische Taschenbücher 5) Münster-New York-München-Berlin: Waxmann

Cavalli-Sforza, L. L. (1996): Genes, Peoples, and Languages. Proceedings of the National Academy of Sciences of the USA, 94, 7719-7724. http://www.pnas.org/content/94/15/7719.full

Csákyová, V. - Szécsényi-Nagy A. - Csösz A. et al. (2016): Maternal Genetic Composition of the Medieval Population from a Hungarian-Slavic Contact Zone in Central Europe. PLOS One, 
11(3): e0151206. DOI: 10.1371/journal.pone.0151206, http://journals.plos.org/plosone/article/ file?id=10.1371/journal.pone.0151206\&type $=$ printable

Csősz A. et al. (2016): Maternal Genetic Ancestry and Legacy of $10^{\text {th }}$ Century AD Hungarians. Scientific Reports, 6, 33446. DOI: 10.1038/srep33446 https://www.nature.com/articles/srep33446

Derks, T. - Roymans, N. (2009): Ethnic Constructs in Antiquity: The Role of Power and Tradition. Amsterdam: Amsterdam University Press, DOI: 10.5117/9789089640789, https://oapen. org $/$ download?type $=$ document $\&$ docid $=340082$

Fernandez-Götz, M. (2008): La construcción arqueológica de la etnicidad. (Serie Keltia 42) Editorial Toxosoutos

Finlayson, C. (2004): Neanderthals and Modern Humans. An Ecological and Evolutionary Perspective. Cambridge: Cambridge University Press

$\mathrm{Fu}$, Q. et al. (2014): Genome Sequence of a 45 000-year-old Modern Human from Western Siberia. Nature, 514, 445-449. DOI: 10.1038/nature13810, https://www.ncbi.nlm.nih.gov/pmc/articles/ PMC4753769/

Fu, Q. et al. (2016): The Genetic History of Ice Age Europe. Nature, 534 (7606), 17993, S. 200 205. DOI:10.1038/nature17993, https://www.ncbi.nlm.nih.gov/pmc/articles/PMC4943878/pdf/ nihms777742.pdf

Gallego Llorente, M. et al. (2016): The Genetics of an Early Neolithic Pastoralist from the Zagros, Iran. Scientific Reports, 6, 31326. DOI: 10.1038/srep31326, https://www.nature.com/articles/ srep31326

Haak, W. et al. (2005): Ancient DNA from the First European Farmers in 7500-Year-Old Neolithic Sites. Science, 310, 5750, 1016-1018. DOI: 10.1126/science.1118725, http://science.sciencemag. org/content/310/5750/1016.full? maxtoshow $=\&$ HITS $=10 \&$ hits $=10 \&$ RESULTFORMAT=\&fulltext $=$ dna\&searchid $=1 \&$ FIRSTINDEX $=0 \&$ resourcetype $=$ HWCIT

Haak, W. et al. (2015): Massive Migration from the Steppe Was a Source for Indo-European Languages in Europe. Nature, 522, 207-211. DOI: 10.1038/nature14317, https://www.researchgate. net/publication/273059488_Massive_migration_from_the_steppe_was_a_source_for_Indo-European_languages_in_Europe

Haber, M. et al. (2016): Ancient DNA and the Rewriting of Human History: Be Sparing with Occam's Razor. Genome Biology, 17, 1. DOI: 10.1186/s13059-015-0866-z, https://genomebiology. biomedcentral.com/articles/10.1186/s13059-015-0866-z

Hagelberg, E. et al. (2015): Ancient DNA: The First Three Decades. Philosophical Transactions of the Royal Society B, 370 20130371; DOI: 10.1098/rstb.2013.0371, http://rstb.royalsocietypublishing.org/content/370/1660/20130371

Hammer, M. F. et al. (2011): Genetic Evidence for Archaic Admixture in Africa. Proceedings of the National Academy of Sciences of the USA, 108, 15123-15128. DOI: 10.1073/pnas.1109300108, http://www.pnas.org/content/108/37/15123.full

Hansen, S. - Müller, J. (2011): Sozialarchäologische Perspektiven: Gesellschaftlicher Wandel 5000-1500 v. Chr. zwischen Atlantik und Kaukasus. Internationale Tagung 15.-18. Oktober 2007 in Kiel (Archäologie in Eurasien) Mainz: Zabern

Herrmann, B. (Hrsg.) (1994): Archäometrie. Naturwissenschaftliche Analyse von Sachüberresten. Berlin: Springer

Herrmann, B. - Hummel, S. (eds.) (1994): Ancient DNA. New York: Springer

Hofmanová, Z. et al. (2016): Early Farmers from across Europe Directly Descended from Neolithic Aegeans. Proceedings of the National Academy of Sciences of the USA, 113, 6886-6891. DOI: 10.1073/pnas.1523951113, http://www.pnas.org/content/113/25/6886.long

Hofreiter, M. et al. (2001): Ancient DNA. Nature Review, 2, 5, 353-359. DOI: 10.1038/35072071, https://www.researchgate.net/publication/200029011_Ancient_DNA 
Hofreiter, M. et al. (2014): The Future of Ancient DNA: Technical Advances and Conceptual Shifts. Bioessays, 37, 284-293. DOI: 10.1002/bies.201400160, http://onlinelibrary.wiley.com/ doi/10.1002/bies.201400160/full

Jones, S. (1997): The Archaeology of Ethnicity. Constructing Identities in the Past and Present. London-New York: Routledge, https://goo.gl/n2AZK6

Keerl, V. (2014): A River Runs Through It - Ancient DNA Data on the Neolithic Populations of the Great Hungarian Plain. Doctoral thesis. Mainz: Johannes Gutenberg University, https://publications.ub.uni-mainz.de/theses/volltexte/2015/4115/pdf/4115.pdf

Knipper, C. et al. (in press): The Migration Period in Europe and the Lombards - A Strontium and Oxygen Isotopes View

Kristiansen, K. (2012): The Bronze Age Expansion of Indo-European Languages: An Archaeological model. In: Prescott, C. - Glørstad, H. (eds.): Becoming European. The Transformation of Third Millennium Northern and Western Europe. Oxford: Oxbow Books

Kuhlwilm, M. et al. (2016): Ancient Gene Flow from Early Modern Humans into Eastern Neanderthals. Nature, 530, 429-433. DOI: 10.1038/nature16544, https://www.ncbi.nlm.nih.gov/pmc/ articles/PMC4933530/

Lazaridis, I. et al. (2014): Ancient Human Genomes Suggest Three Ancestral Populations for Present-day Europeans. Nature, 513, 409-413. DOI: 10.1038/nature13673, https://www.ncbi.nlm. nih.gov/pmc/articles/PMC4170574/

Lazaridis, I. et al. (2016): Genomic Insights into the Origin of Farming in the Ancient Near East. Nature, 536, 419-424. DOI: 10.1038/nature19310, https://www.ncbi.nlm.nih.gov/pmc/articles/ PMC5003663/

Mallick, S. et al. (2016): The Simons Genome Diversity Project: 300 Genomes from 142 Diverse Populations. Nature, 538, 201-206. DOI: 10.1038/nature18964, https://www.ncbi.nlm.nih.gov/ pmc/articles/PMC5161557/

Martiniano, R. et al. (2016): Genomic Signals of Migration and Continuity in Britain before the Anglo-Saxons. Nature Communications, 7, 10326. DOI: 10.1038/ncomms10326, https://www. ncbi.nlm.nih.gov/pmc/articles/PMC4735653/

Mathieson, I. et al. (2015): Genome-wide Patterns of Selection in 230 Ancient Eurasians. Nature, 528, 499-503. DOI: 10.1038/nature16152, https:/www.ncbi.nlm.nih.gov/pmc/articles/ PMC4918750/

Orlando, L. et al. (2015): Reconstructing Ancient Genomes and Epigenomes. Nature Reviews Genetics, 16, 395-408 DOI: 10.1038/nrg3935.

Özdogan, M. (1997): The beginning of the Neolithic economies in southeastern Europe: an Anatolian perspective. Journal of European Archaeology, 5, 1-33. DOI: 10.1179/ 096576697800660267

Pääbo, S. (1985): Molecular Cloning of Ancient Egyptian Mummy DNA. Nature, 314, 644-645. DOI: 10.1038/314644a0, https://www.researchgate.net/publication/19170740_Molecular_cloning_of_Ancient_Egyptian_mummy_DNA

Pääbo, S. et al. (2004): Genetic Analyses from Ancient DNA. Annual Review of Genetics, 38, 645-679. DOI: 10.1146/annurev.genet.37.110801.143214

Pinhasi, R. et al. (2012): The Genetic History of Europeans. Trends in Genetics, 28: 496-505. DOI: 10.1016/j.tig.2012.06.006.

Pohl, W. (2008): Migration und Ethnogenesen der Langobarden aus Sicht der Schriftquellen. In: Bemman, J. - Schmauder, M. (Hrsg.): Kulturwandel in Mitteleuropa. Langobarden, Awaren, Slawen. Bonn: Habelt, 13-42.

Posth, C. et al. (2016): Pleistocene Mitochondrial Genomes Suggest a Single Major Dispersal of Non-Africans and Late Glacial Population Turnover in Europe. Current Biology, 26, 6, S. 
827-833. DOI: 10.1016/j.cub.2016.01.037 http://www.cell.com/current-biology/fulltext/S09609822(16)00087-7

Racimo, F. et al. (2015): Evidence for Archaic Adaptive Introgression in Humans. Nature Reviews Genetics, 16, 359-371. DOI: 10.1038/nrg3936, https://www.ncbi.nlm.nih.gov/pmc/articles/ PMC4478293/

Rasmussen, M. et al. (2014): The Genome of a Late Pleistocene Human from a Clovis Burial Site in Western Montana. Nature, 506, 225-229. DOI: 10.1038/nature13025, https://www.ncbi.nlm. nih.gov/pubmed/?term=The + genome + of $+\mathrm{a}+$ Late + Pleistocene + human + from $+\mathrm{a}+$ Clovis + burial+site+in+western+Montana

Reich, D. et al. (2010): Genetic History of an Archaic Hominin Group from Denisova Cave in Siberia. Nature, 468, 1053-1060. DOI: 10.1038/nature09710, https://www.ncbi.nlm.nih.gov/pmc/ articles/PMC4306417/

Richards, M. (2003): The Neolithic Invasion of Europe. Annual Review of Anthropology, 135-162. DOI: 10.1146/annurev.anthro.32.061002.093207, http://arheo.ffzg.unizg.hr/ska/tekstovi/neolithic_invasion.pdf

Richards, M. et al. (1993): Archaeology and Genetics: Analysing DNA from Skeletal Remains. World Archaeology, 25, 18-28. DOI: 10.1080/00438243.1993.9980225

Sankararaman, S. et al. (2014): The Genomic Landscape of Neanderthal Ancestry in Ppresent-day Humans. Nature, 507, 7492, 354-357. DOI: 10.1038/nature12961

Sankararaman, S. et al. (2016): The Combined Landscape of Denisovan and Neanderthal Ancestry in Present-Day Humans. Current Biology, 26, 1241-1247. DOI: 10.1016/j.cub.2016.03.037, https://www.ncbi.nlm.nih.gov/pmc/articles/PMC4072735/

Schiffels, S. et al. (2016): Iron Age and Anglo-Saxon Genomes from East England Reveal British Migration History. Nature Communications, 7, 10408. DOI: 10.1038/ncomms10408, https:// www.ncbi.nlm.nih.gov/pmc/articles/PMC4735688/

Slatkin, M. - Racimo, F. (2016): Ancient DNA and Human History. Proceedings of the National Academy of Sciences of the USA, 113, 6380-6387. DOI: 10.1073/pnas.1524306113, http://www. pnas.org/content/113/23/6380.full

Stoneking, M. (1995): Ancient DNA: How do you know when you have it and what can you do with it? American Journal of Human Genetics, 57, 1259-1262. https://www.ncbi.nlm.nih.gov/pmc/ articles/PMC1801427/pdf/ajhg00038-0006.pdf

Stringer, C. (2016): The Origin and Evolution of Homo sapiens. Philosophical Transactions of the Royal Society B, 371, 1698, 20150237. DOI: 10.1098/rstb.2015.0237, http://rstb.royalsocietypublishing.org/content/royptb/371/1698/20150237.full.pdf

Szécsényi-Nagy, A. (2015): Molecular Genetic Investigation of the Neolithic Population History in the Western Carpathian Basin. PhD thesis. Mainz: Johannes Gutenberg University, https:// publications.ub.uni-mainz.de/theses/volltexte/2015/4075/pdf/4075.pdf

Szécsényi-Nagy, A. et al. (2015): Tracing the Genetic Origin of Europe's First Farmers Reveals Insights into Their Social Organization. Proceedings of the Royal Society B, 282, 20150339. DOI: 10.1098/rspb.2015.0339 http://rspb.royalsocietypublishing.org/content/282/1805/20150339.long

Szécsényi-Nagy, A. et al. (2017): The maternal genetic make-up of the Iberian Peninsula between the Neolithic and the Early Bronze Age. bioRxiv, DOI: 10.1101/106963, https://www.biorxiv. org/content/early/2017/08/21/106963.full.pdf+html

Szécsényi-Nagy, A. - Keerl, V. - Jakucs, J. - Bánffy, E. - Alt, K. W. (2014): Ancient DNA Evidence for a Homogeneous Maternal Gene Pool in Sixth Millennium cal BC Hungary and the Central European LBK. In: Whittle, A. - Bickle, P. (eds.): Early Farmers: The View from Archaeology and Science. (Proceedings of the British Academy, 198), 71-93. DOI: 10.5871/bacad/9780197265758.003.0005, https://goo.gl/65i8Xh 
Tütken, T. - Knipper, C. - Alt, K. W. (2008): Mobilität und Migration im archäologischen Kontext: Informationspotential von Multi-Element-Isotopenanalysen ( $\mathrm{Sr}, \mathrm{Pb}, \mathrm{O})$. In: Bemman, J. Schmauder, M. (Hrsg.): Kulturwandel in Mitteleuropa. Langobarden, Awaren, Slawen. Bonn: Habelt, 13-42.

Vai, S. et al. (2015): Genealogical Relationships between Early Medieval and Modern Inhabitants of Piedmont. PLOS ONE, 10(1): e0116801. DOI: 10.1371/journal.pone.0116801, http://journals. plos.org/plosone/article?id=10.1371/journal.pone.0116801

Vernot, B. - Akey, J. M. (2014): Resurrecting Surviving Neanderthal Lineages from Modern Human Genomes. Science, 28, 343, 6174, 1017-1021. DOI: 10.1126/science.1245938, https://www. researchgate.net/publication/259984758_Resurrecting_Surviving_Neandertal_Lineages_ from_Modern_Human_Genomes

Vida T. (2008): Die Langobarden in Pannonien. In: Landschaftsverband Rheinland/Rheinisches Landesmuseum Bonn (Hrsg.): Die Langobarden. Das Ende der Völkerwanderungszeit. Darmstadt: Primus Verlag, 72-89. https://www.researchgate.net/publication/210371416_Die_Langobarden_in_Pannonien

Willerslev, E. - Cooper, A (2005): Ancient DNA. Proceedings of the Royal Society B, 272, 1558, 3-16. DOI: 10.1098/rspb.2004.2813 https://www.ncbi.nlm.nih.gov/pmc/articles/PMC1634942/

Wood, B. - Lonergan, N. (2008): The Hominin Fossil Record: Taxa, Grades and Clades. Journal of Anatomy, 212, 354-376. DOI: 10.1111/j.1469-7580.2008.00871.x, https://www.ncbi.nlm.nih. gov/pmc/articles/PMC2409102/

Xie, C. Z. et al. (2007): Evidence of Ancient DNA Reveals the First European Lineage in Iron Age Central China. Proceedings of the Royal Society: B, 274, 1618, 1597-1602. DOI: 10.1098/ rspb.2007.0219, http://rspb.royalsocietypublishing.org/content/274/1618/1597.long

Zvelebil, M. (2001): The Agricultural Transition and the Origins of Neolithic Society in Europe. Documenta Praehistorica, 28, 1-26. DOI: 10.4312/dp.28.1, https://www.researchgate.net/publication/291911861_The_agricultural_transition_and_the_origins_of_Neolithic_society_in_ Europe 